\title{
EXPERIMENTAL REDUCTION OF LANDFILL EMISSIONS BASED ON DIFFERENT CONCEPTS: THE PAF MODEL
}

\author{
Raffaello Cossu \\ IMAGE, University of Padua, Italy
}

Davide Rossetti

Spinoff Srl, Italy

\begin{abstract}
A laboratory column test and a large lysimeter reactor were set up to simulate the behaviour of MBP waste disposal in different concept landfills. In particular, three different options were used to study the reduction of long term environmental impact and to reach the sustainability: mechanical-biological pretreatment waste disposal, natural and forced aeration and flushing. The lab-scale test was set up to compare the different behaviour of waste with anerobic, aerobic and semiaerobic conditions, flushing. The lysimeter reactor simulated the combination of the three different options (PAF model). The results presented in this paper show that this combination seems to synergize the positive effects in terms of leachate and gas emissions.
\end{abstract}

\section{INTRODUCTION}

Landfills of municipal solid waste produce an environmental impact which can last for several decades. The typical environmental problems are due to dangerous leachate and biogas emissions. In many countries, the new waste management regulations indicate the recycling and pretreatment way to reduce the impact of the waste landfilling. Nevertheless, in a integrated waste management system the landfill still plays a primary role. Therefore, the actual researches go not only in the way of pretreatment waste system but also to create a landfill reactor that allows a reduction of dangerous emissions in relatively short time. The objective of the modern studies is the sustainability of the landfill.

The different options for the sustainability objective that we consider are the pretreatment of waste and the in situ aeration and flushing, in contrast with the typical technology of landfilling based on anaerobic degradation, gas extraction, impermeable surface cover.

The pretreatment of waste with mechanical-biological or thermal processes allows to reduce the waste potential environmental impact before the landfilling (among others Leikam and Stegmann, 1997; Scheelhase and Bidlingmaier, 1997). The in situ aeration of 
landfill with forced aeration (aerobic landfill) or natural convection aeration (semiaerobic landfill) allows to convert the anaerobic processes in aerobic waste degradation (Matsuto et al., 1991; Matsufuji et al., 2000; Hanashima, 1999; M. Hudgins, S. Harper, 1999);

The in situ and off site flushing of waste enables the solubilization of substances and consequently their transport in liquid form (Blakey et al., 1997; Kamik and Parry, 1997; Novella et al.,1997; Purcell et al., 1997; Walker et al., 1997; Wingfield-Hayes et al., 1997; Robinson 1998; Higuchi and Hanashima, 1999).

The main purpose of the research presented in this paper is to study the disposal of MBP waste in semiaerobic-flushing concept landfill (Pretreated, Aerated, Flushing: PAF model).

The PAF model simulates a MBP landfill with a semiaerobic aeration system and in situ flushing concept.

The present paper refers to the results obtained after 26 months of lysimeter test and 120 days of lab-scale test, and reports the evolution of leachate emissions and biogas during the test.

\section{MATERIALS AND METHODS}

\subsection{Lab-scale test}

Six columns were set up to simulate different concepts landfill. Table 2.1 reports the different operational conditions of the columns.

Table 2.1. Operative conditions of the different lab columns

\begin{tabular}{llll}
\hline Column & Material & Operative Conditions & Landfill Concept \\
\hline A & MSW & Anaerobic & Traditional landfill \\
B & MBP & Anaerobic & Pre-treated landfill \\
C & MBP & Anaerobic with high water input & Flushing bioreactor \\
D & MBP & Aerobic - high air inflow & Aerated landfill \\
E & MBP & $\begin{array}{l}\text { Aerobic - low and } \\
\text { discontinuous air inflow } \\
\text { Ferobic - low and } \\
\text { fiscontinuous air inflow, high }\end{array}$ & Semiaerobic landfill \\
& MBP & PAF model \\
& & water input & \\
\hline
\end{tabular}

The columns, $100 \mathrm{~cm}$ higher with a diameter of $18 \mathrm{~cm}$, were used to simulate different landfill concepts. The results about leachate and biogas analysis were compared to study the different behaviour of reactors. The columns $\mathrm{C}$ and $\mathrm{F}$ were fed with a high water input until a liquid/solid ratio $(\mathrm{L} / \mathrm{S})=7,5$ was reached after a period of 120 days, three times higher than the others columns. Column A was filled with unprocessed MSW; the other 
columns were filled with mechanical biological pretreated (MBP) refuse from the Legnago Plant (Verona, Italy).

\subsection{Lysimeter Test}

The PAF model consists of a square base column with an internal dimension of $0,64 \mathrm{~m}^{2}$ and a vertical height of $3 \mathrm{~m}$. The column was constructed with steel and plexiglas. For the manteinance of the internal temperature, the column was insulated with a $10 \mathrm{~cm}$ of polistyrene panels. The PAF model was filled with approximately $750 \mathrm{~kg}$ of emechanicalbiological pretreated waste from the Legnago plant.

The lower part of the PAF model consists of $70 \mathrm{~cm}$ gravel drainage with a perforated HDPE pipe (300 mm diameter) inserted to create an air flow from the ambient to the waste mass due to a natural convective mechanism. The air convective flow is created by the gradient of temperature between the waste and the external ambient. This system simulated the semiarobic landfill technology. The lysimeter has different measuring points for monitoring of biogas composition and temperature.

Figure 2.1 shows the large lysimeter PAF model. Initially, the gas composition was measured in points 1-3G. Then, to control the gas composition with a larger diameter probe inside the waste, 1-3T points were considered.

The bottom drainage allowed to collect the leachate for the analysis of different parameters.

Periodically, leachate was collected and analysed for $\mathrm{pH}, \mathrm{BOD}_{5}, \mathrm{COD}, \mathrm{TKN}, \mathrm{N}-\mathrm{NH}_{4}{ }^{+}, \mathrm{N}-$ $\mathrm{NO}_{x}$ and heavy metals.

With a portable IR analyser the biogas composition was measured in terms of $\mathrm{CO}_{2}, \mathrm{CH}_{4}$, $\mathrm{O}_{2}$.

Rainfall was simulated for the first 15 months by feeding the lysimeter with distilled water. Then, the lysimeter was open to the natural rainfall and water was added manually to collect periodically the leachate.

The lysimeter was not fed with water for 30 days after starting the test to enable the air flow due to natural convection. This first period was useful to understand the behaviour of the system. Then, for about 60 days the lysimeter was fed with a high amount of water to simulate a flushing with high irrigation rate. The flushing rate after 60 days was equivalent to a annual precipitation rainfall 2,82 times higher than a typical Padua annual precipitation rainfall of $800 \mathrm{~mm}$. In the following months the flushing rate was reduced. The simulated precipitation rainfall reached at the $15^{\text {th }}$ month was about $900 \mathrm{~mm} / \mathrm{year}$ and at the end of the test it was about $800 \mathrm{~mm} / \mathrm{year}$.

\subsection{Waste characteristics}

The quality of MSW and MBP waste used in the columns and lysimeter was determined in terms of different parameters. Table 1 and 2 show the results of the analysis on solids 


\section{KALMAR ECO-TECH'03}

Bioremediation and Leachate Treatment

KALMAR, SWEDEN, November 25-27, 2003

and eluate from leaching tests. The leaching tests were carried out at a solid/liquid ratio of $1 / 20$, with distilled water and a solution of $1 \mathrm{~N}$ of acetic acid as elution liquids, mixed in a Jar Test apparatus for 24 hours. The respiration index for four days (RI4) was measured using the Sapromat respirometer (Voith Gmbh).
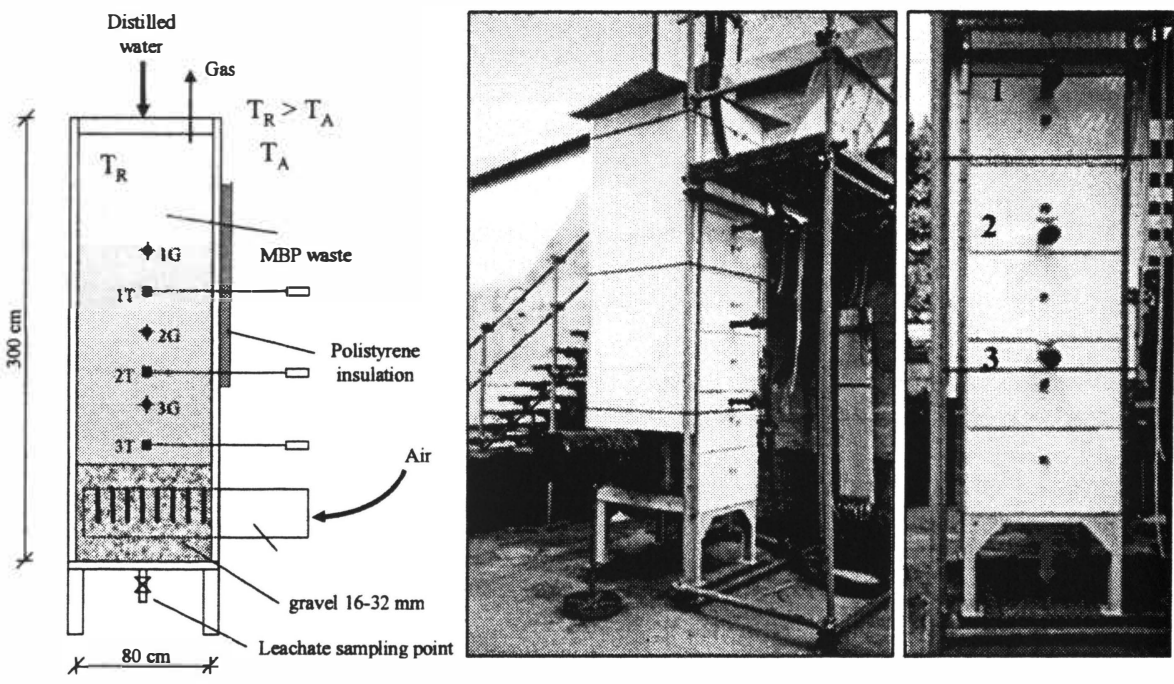

Figure 2.1 - The lysimeter PAF model (1-3T: temperature and biogas measuring points; 1-3G biogas measuring points; $T_{R} \mathrm{e}=$ waste mass temperature; $T_{A} \mathrm{e}=$ ambient temperature)

Table 2.2 - Characteristics of the MSW and MBP waste.

\begin{tabular}{lcc}
\hline Determinand & MSW & MBP \\
\hline pH & 7.2 & 8 \\
Moisture content (\%) & 55 & 33 \\
TVS (\%) & 50 & 44 \\
TOC (gC/kg TS) & 293 & 208 \\
$\mathrm{RI}_{4}\left(\mathrm{gO}_{2} / \mathrm{kg} \mathrm{TS}\right)$ & 148 & 9,5 \\
Total Humic substances (\%) & $\mathbf{8 , 9}$ & $\mathbf{8 , 2}$ \\
\hline
\end{tabular}

Table 2.3 - Results of elution tests with distilled water and a solution with $1 N$ acetic acid on MSW waste and MBP waste.

\begin{tabular}{|c|c|c|}
\hline Determinand & MBP & MSW \\
\hline & \multicolumn{2}{|c|}{ distilled water } \\
\hline $\mathrm{pH}$ & 7,1 & 5,7 \\
\hline $\mathrm{BOD}_{5}(\mathrm{mg} / \mathrm{l})$ & 290 & 1850 \\
\hline
\end{tabular}


KALMAR ECO-TECH'03

Bioremediation and Leachate Treatment

KALMAR, SWEDEN, November 25-27, 2003

\begin{tabular}{lcc}
$\mathrm{COD}(\mathrm{mg} / \mathrm{l})$ & 1085 & 2283 \\
$\mathrm{BOD}_{5} / \mathrm{COD}$ & 0,27 & 0,81 \\
$\mathrm{TKN}(\mathrm{mgN} / \mathrm{l})$ & 48 & 45 \\
$\mathrm{NH} 3(\mathrm{mgN} /)$ & 13,2 & 14,8 \\
\hline \multicolumn{3}{c}{ acetic acid } \\
\hline $\mathrm{Cd}(\mathrm{mg} / \mathrm{l})$ & 0,01 & $<0,01$ \\
$\mathrm{Zn}(\mathrm{mg} / \mathrm{l})$ & 2,19 & 2,19 \\
$\mathrm{Ni}(\mathrm{mg} / \mathrm{l})$ & 0,18 & 0,18 \\
$\mathrm{~Pb}(\mathrm{mg} / \mathrm{l})$ & 0,53 & 0,53 \\
$\mathrm{Cu}(\mathrm{mg} / \mathrm{l})$ & 0,66 & 0,66 \\
$\mathrm{Fe}(\mathrm{mg} / \mathrm{l})$ & 1,09 & 1,09 \\
$\mathrm{Cr}(\mathrm{mg} / \mathrm{l})$ & 0,27 & 0,27 \\
\hline
\end{tabular}

\section{RESULTS AND DISCUSSION}

\subsection{Lab-scale test}

\subsubsection{Leachate}

The results about some parameters analyzed in the leachate are given in Figure 3.1.

The column A showed high concentrations of $\mathrm{COD}, \mathrm{BOD}_{5}$ and $\mathrm{NH}_{3}$ for all the duration of the test compared to the other columns (COD $=50000-20000 \mathrm{mg} / \mathrm{l}, \mathrm{BOD}_{5}=20000$ $\left.10000 \mathrm{mg} / \mathrm{l}, \mathrm{NH}_{3}=900-400 \mathrm{mg} / \mathrm{l}\right)$. At the end of the test, column A showed the highest concentrations of all measured parameters in the leachate. Values around $30000 \mathrm{mg} / \mathrm{l}$ for COD and 1300-1800 mgN/l were also observed for column B. The highest reduction of BOD was observed for the aerobic column D, with a final concentration of about $35 \mathrm{mg} / \mathrm{l}$. Column $\mathrm{C}$ and $\mathrm{F}$ showed the highest reduction for $\mathrm{COD}$ and $\mathrm{NH}_{3}$ with concentrations of about $370 \mathrm{mg} / \mathrm{l}$ and $750 \mathrm{mg} / \mathrm{l}$ respectively of COD and 5-6 $\mathrm{mgN}-\mathrm{NH}_{4}{ }^{+} / 1$ after 120 days.

The column $\mathrm{E}$ showed a low reduction of the different parameters compared to column $\mathrm{F}$ and $\mathrm{D}$. In column $\mathrm{F}$ is very evident the flushing effect compared to column $\mathrm{E}$. In the column $\mathrm{D}$, the high air flow input produced a reduction specially for $\mathrm{BOD}_{5}$ but also $\mathrm{NH}_{3}$ concentration was about $10 \mathrm{mgN} / \mathrm{l}$ at the end of the test.

The flushing produced high quantity of leachate and consequently high loads of organic substance and nitrogen compared the columns without flushing. Despite of this, the column $\mathrm{F}$ showed a lower cumulative release of all parameters than column $\mathrm{C}$, with differences within a range of $16-28 \%$. The highest value is related to NHeg.

\subsubsection{Biogas}

Figure 3.2 shows the evolution of biogas in the columns. The anaerobic disposal of $\mathrm{MBP}$ waste seems to accelerate the methanogenic phase, with a very short period of acid phase with $\mathrm{pH}=6-6,5$, as results by observing the $\mathrm{B}$ column. The gas produced by the column 
D had a high concentration of oxygen and, especially for the initial period, a concentration of carbon dioxide of about 5-12\%, but not methane. This concentration reduced after 30 days, reaching values of about $1-2 \%$. The column A showed a $\mathrm{pH}$ of about 5,5 for all the test period, consequently an inhibition of methanogenic phase was established.

Columns $\mathrm{D}, \mathrm{E}$ and $\mathrm{F}$ showed the highest $\mathrm{pH}(7-7,5)$. Columns $\mathrm{E}$ and $\mathrm{F}$ showed a concentration of about $20-25 \%$ of $\mathrm{CO}_{2}$ and peaks of methane of about $10-15 \%$. The presence of methane is due to the operational conditions of $\mathrm{E}$ and $\mathrm{F}$ columns, with a discontinuous aeration. The oxygen was about $15-20 \%$ in column $\mathrm{D}$, whereas in columns $\mathrm{E}$ and $\mathrm{F}$ it was about $0-2 \%$.

The simultaneous aeration and flushing seems to optimize the positive effects on leachate and biogas, with a high concentrations reduction due to aerobic conditions and a washing effect.

\subsection{Large PAF model lysimeter test}

\subsubsection{Leachate}

$\mathrm{COD}$ and $\mathrm{BOD}_{5}$

$\mathrm{COD}$ and $\mathrm{BOD}_{5}$ graphs are given in Figure 3.3. At the beginning of the test $\mathrm{COD}$ and $\mathrm{BOD}_{5}$ were very high with a peak of $27500 \mathrm{mg} / \mathrm{l}$ and 12500 respectively. During the first 4 months the flushing was very effective, so the concentrations decreased very much, reaching values around $9400 \mathrm{mg} / \mathrm{l}$ and $320 \mathrm{mg} / \mathrm{l}$ for COD and $\mathrm{BOD}_{5}$ respectively.

After the $4^{\text {th }}$ month it was decided to reduce the flushing rate to see whether the effect of the natural aeration would be more evident. At the $8^{\text {th }}$ month the concentrations in the leachate were very low compared to the initial values $(C O D=9200 \mathrm{mg} / \mathrm{l}, \mathrm{BOD}=40$ $\mathrm{mg} / \mathrm{l})$.

After the $8^{\text {th }}$ month a stabilization of the concentrations of the leachate, with even an increase trend especially for COD was observing. As it is shown in Figure 3.5, the ambient temperature in this period increased after winter. A probable increase of the bacteria activity produced a new release of dissolved organic substances in the leachate.

The final values at the end of the test were $30 \mathrm{mg} / \mathrm{l}$ for BOD5 and $3150 \mathrm{mg} / \mathrm{l}$ for COD.

The $\mathrm{BOD}_{5} / \mathrm{COD}$ ratio was very low for a long time, with values around 0,015 .

The presence of a high COD concentration with a low BOD concentration was probably due in part to humic substances, which are stabilized to further biological degradation.

The analysis of humic substances concentrations gave an average value of about $400 \mathrm{mg} / \mathrm{l}$ for the last two leachate samples.

$\mathrm{pH}$ and Nitrogen 
KALMAR ECO-TECH'03

Bioremediation and Leachate Treatment

KALMAR, SWEDEN, November 25-27, 2003

During the high rate flushing phase, the reduction was high, reaching a concentration of $190 \mathrm{mg} / \mathrm{l}$ after 4 months. A peak of NOx reached a concentration of $2000 \mathrm{mg} / \mathrm{l}$ after the first phase without water alimentation. Figure 3.4 shows the evolution of $\mathrm{TKN}, \mathrm{NH}_{3}$, $\mathrm{NOx}$ and $\mathrm{pH} . \mathrm{NH}_{3}$ was very high initially, with a concentration of about $1500 \mathrm{mg} / \mathrm{l}$.


Figure 3.1 - Evolution of different parameters in the leachate of the columns after 120 days.


Figure 3.2 - Evolution of biogas composition in the columns.

As it is shown in Figure 3.3 for COD and BOD, an increase of all parameter concentrations was observed after the $14^{\text {th }}$ month, in accordance with a temperature increase. In this period the TKN increased much more than $\mathrm{NH}_{3}$, and this way probably due to an increase of organic nitrogen release. After flushing, the NOx concentrations stabilized around an average value of $330 \mathrm{mg} / \mathrm{l}$. The ammonia concentration at the end of 
the test was about $16-19 \mathrm{mg} / \mathrm{l}$. This is a very low value, compared to the typical ammonia values of leachate. Ammonia is a typical leachate long environmental impact, with decreased time of tens of years.

The effect of flushing is evident in the first months, with a remarkable reduction of concentration, equal to $84 \%$ in 120 days for ammonia. The effect of natural convection aeration is an ammonia-nitrate conversion. This seems to produce a very low ammonia concentration in leachate.

The $\mathrm{pH}$ was always above 7 , reaching values of about 8,7 at the end of the test.

\section{$\underline{\text { Heavy Metals }}$}

The concentrations of heavy metals did not show a decrease like the other parameters in the leachate. $\mathrm{Fe}, \mathrm{Cu}$ and $\mathrm{Zn}$ showed the higher initial concentrations. The same thing was for the final concentrations, but only Fe showed a remarkable decrease in the leachate, with an initial concentration of $54,5 \mathrm{mg} / \mathrm{l}$ and a final concentration of $7,3 \mathrm{mg} / \mathrm{l}$.

\subsubsection{Biogas and temperature}

Figure 3.5 shows the gas composition evolution in 1-3G and 1-3T points. Figure 3.6 shows the waste temperature compared to external ambient temperature.

The 1T point showed a high oxygen content after the $8^{\text {th }}$ month for the effect of an air infiltration through the upper waste surface due to a height waste reduction for compaction and a consequent 1T approach to the upper surface.

The methane reached peak concentrations of about $15 \%$ in the first four months, during the flushing phase. The peak of oxygen in the first month in the $3 \mathrm{G}$ point is due to a probable presence of an air flow from the ambient to the waste. After starting the flushing, the gas composition showed a methane and carbon dioxide increase, with peaks of $10-15 \%$ and $20-25 \%$ respectively. The temperature inside the waste was very high in the first month compared to the ambient temperature, with values around $658 \mathrm{C}$ for the $2 \mathrm{~T}$ point.

After starting the flushing, the temperature decreased reaching values of about $35-40^{\circ} \mathrm{C}$. With the ambient temperature reduction due to winter, the gas composition showed an increase of the oxygen presence probably due to air infiltration and a very low bacteria activity.

The following temperature probably increased with spring and summer seasons and produced an increase of bacteria activity, an oxygen reduction due to biological aerobic degradation and a consequent carbon dioxide increase. The low flushing rate after the first 4 months probably allowed the oxygen to infiltrate better into the waste mass for convection and diffusion processes. The methane was very low, with concentrations of about $0-1 \%$. 


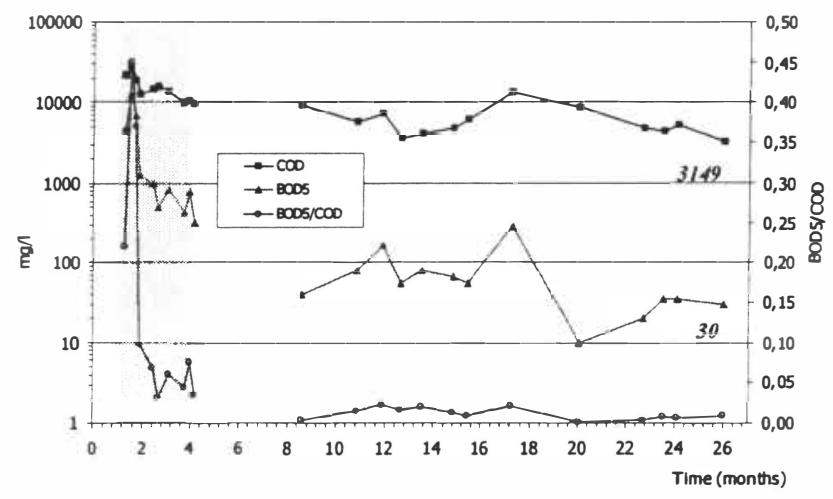

Figure 3.3. $C O D$ and $B O D_{5}$ evolution in the leachate of the lysimeter

The production of carbon dioxide showed an increase due to relative high temperature which allowed bacteria activity. The consumption of oxygen during this phase is remarkable. In general, the infiltration of air by natural convection was difficult with a high flushing rate. The result is an increase of the methane production due to anaerobic conditions instauration.

The temperature gradient allows create an air flow from the ambient to the waste through the pipe in the drainage. The gradient seems to be effective also with a difference of few degrees between the temperatures.

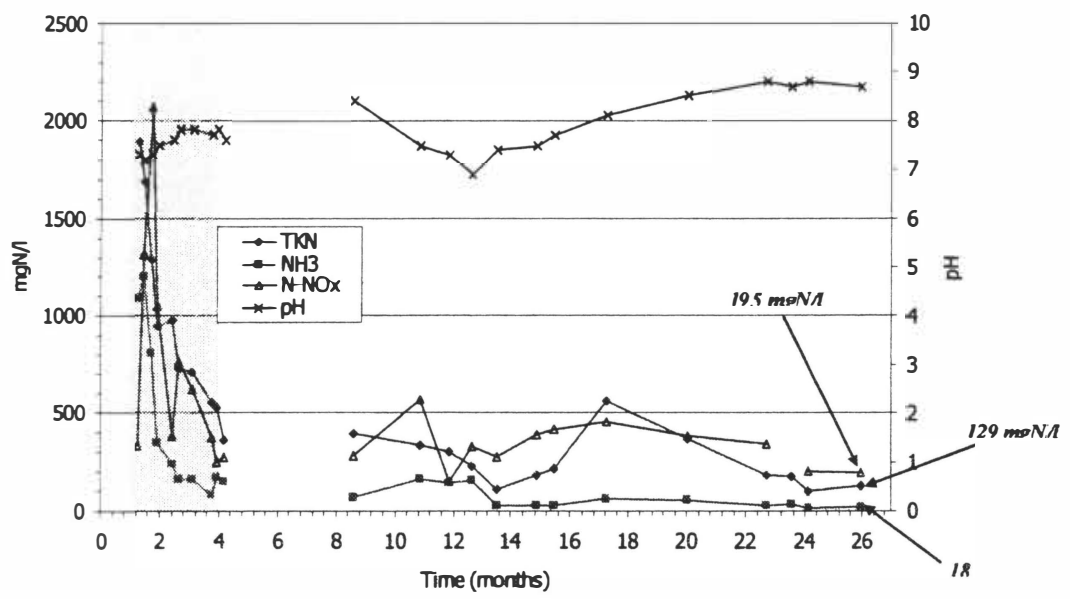

Figure 3.4 -Evolution of Nitrogen different forms and $\mathrm{pH}$ in the leachate of the lysimeter 
KALMAR ECO-TECH'03

Bioremediation and Leachate Treatment

KALMAR, SWEDEN, November 25-27, 2003

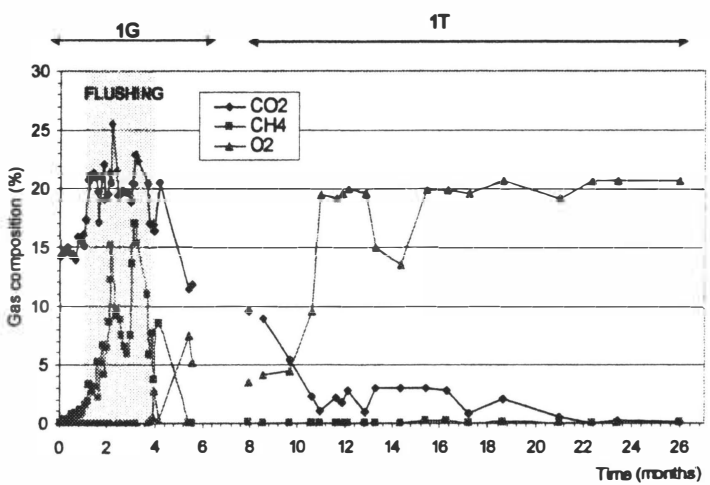

Figure 3.5-Evolution of $1 G$ and $1 T$ point gas composition.
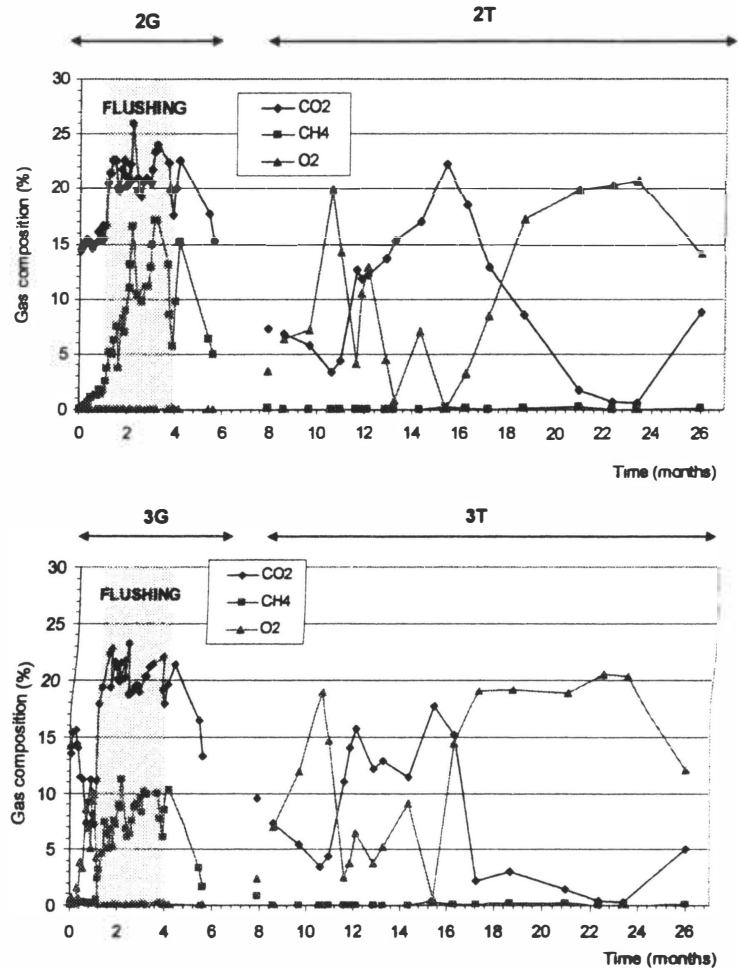

Figure 3.5-Evolution of 2-3G and 2-3T points gas composition. 
KALMAR ECO-TECH'03

Bioremediation and Leachate Treatment

KALMAR SWEDEN, November 25-27, 2003

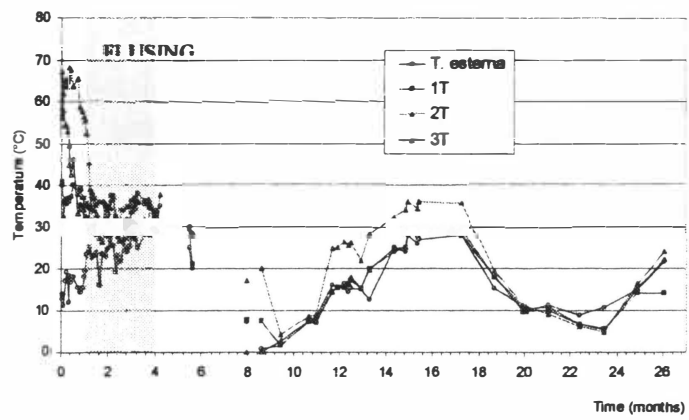

Figure 3.6 - Evolution of temperatures.

\subsubsection{Characterization of the residues}

Table shows the characteristics of the waste at the end of the test. As it is shown in Table 3.1 , at the end of the test the residues presented a remarkable reduction of respirometric index, total volatile solids and total nitrogen. In terms of humic substances content, the residues presented an increase of total humic substances and total humic carbon, compared to the original content. The presence of an increasing humic substances content was probably due to stabilization processes of the waste.

The analysis on eluate from leaching test showed a decreased especially for $\mathrm{BOD}_{5}$, with a reduction of $\mathrm{BOD}_{5} / \mathrm{COD}$ in the eluate from distilled water leaching test.

Table 3.1-Characteristics of the residues after the lysimeter test.

\begin{tabular}{lc}
\hline Determinand & MBP \\
\hline $\mathrm{pH}$ & 8,1 \\
Moisture content (\%) & 25 \\
$\mathrm{TVS}(\%)$ & 34 \\
$\mathrm{RU}_{4}(\mathrm{gO} / \mathrm{kg} \mathrm{TS})$ & 3,95 \\
Total humic substances (\%) & 32,5 \\
\hline & \\
\hline Determinand & MBP \\
\hline & distilled water \\
\cline { 2 - 2 } $\mathrm{pH}$ & 8 \\
$\mathrm{BOD}(\mathrm{mg} /)$ & 14 \\
$\mathrm{COD}(\mathrm{mg} / \mathrm{l})$ & 70 \\
$\mathrm{BOD} / \mathrm{COD}$ & 0,11 \\
$\mathrm{TKN}_{(\mathrm{mgN} / \mathrm{l})}$ & 6,5 \\
$\mathrm{NH}_{3}(\mathrm{mgN} /)$ & 3,3 \\
\hline
\end{tabular}


KALMAR ECO-TECH'03

Bioremediation and Leachate Treatment

KALMAR, SWEDEN, November 25-27, 2003

\begin{tabular}{lc}
$\mathrm{COD}(\mathrm{mg} / \mathrm{l})$ & 70 \\
$\mathrm{BOD}_{5} / \mathrm{COD}$ & 0,11 \\
$\mathrm{TKN}(\mathrm{mgN} / \mathrm{l})$ & 6,5 \\
$\mathrm{NH}_{3}(\mathrm{mgN} / \mathrm{l})$ & 3,3 \\
\hline & acetic acid \\
\hline $\mathrm{Cd}(\mathrm{mg} / \mathrm{l})$ & $<0,001$ \\
$\mathrm{Zn}(\mathrm{mg} / \mathrm{l})$ & 1,05 \\
$\mathrm{Ni}(\mathrm{mg} / \mathrm{l})$ & 0,02 \\
$\mathrm{~Pb}(\mathrm{mg} / \mathrm{l})$ & $<0,001$ \\
$\mathrm{Cu}(\mathrm{mg} / \mathrm{l})$ & $<0,001$ \\
$\mathrm{Fe}(\mathrm{mg} / \mathrm{l})$ & 0,02 \\
$\mathrm{Cr}(\mathrm{mg} / \mathrm{l})$ & $<0,001$ \\
\hline
\end{tabular}

\section{CONCLUSIONS}

The environmental impact of a municipal solid waste landfill is a consequent of dangerous long time leachate and biogas emissions.

A large lysimeter test and a lab scale column test were set up to study the effiects of MBP landfilling with a simultaneous application of flushing and aeration by natural convection process (PAF model: Pretreated, Aerobic, Flushing).

The lab scale column test was carried out to compare different landfill models: traditional anaerobic landfill, aerobic and semiaerobic landfill and the PAF model landfill.

The results after 120 days of lab scale test showed that PAF model reached a very low concentration of ammonia $(6 \mathrm{mgN} / \mathrm{l})$ and $\mathrm{BOD}_{5}(54 \mathrm{mg} / \mathrm{l})$. The effiect of flushing on the PAF model is very effective, as it can be seen comparing the behaviour of different models. The aeration is evident comparing the PAF model with the only flushing column in anaerobic conditions. In this case is evident the reduction of load release of BOD and COD in the PAF model leachate. The column test demonstrated as the pre-treatment of waste could reduce the long term environmental impact, especially in terms of methane production, reducing the duration of initial acid phase in anaerobic conditions. This does not seem to be sufficient for reducing the dangerous leachate emissions in relatively short time.

The lysimeter PAF model showed interesting results after a two-years test.

As in the lab-scale column, the high rate flushing produced a high reduction effect on all parameter concentrations in the leachate. After reducting the flushing rate, the leachate showed a continue reduction especially for BOD and ammonia and final concentrations of $30 \mathrm{mg} / \mathrm{l}$ and $18 \mathrm{mgN} / \mathrm{l}$ respectively. The $\mathrm{pH}$ was always above 7 . 
The application of a high flushing rate in the lysimeter produced the effect to reduce air infiltration. This can be seen in the variation of gas composition after starting the flushing, with an increase of methane due to a formation of anaerobic conditions zone.

The air infiltration seems to be effective also with a few degrees difference in terms of temperature gradient between the waste and external ambient. The high rate flushing produced a reduction of waste temperature and consequently of the temperature gradient and this can hinder the air infiltration.

The aeration by natural convection (semiaerobic system) seems to be more effective with a lower flushing rate.

The results demonstrated that the application of a high flushing rate produces a remarkable reduction of all concentrations in the leachate.

To apply the PAF model in large scale, the semiaerobic system should be applied since the projectation phase. The costs of realization of a semiaerobic landfill are securely cheaper compared to aerobic landfills where high costs are due to installations and plant management.

The concept of flushing could be seen as a system that allows the rainfall water to infiltrate through the surface cover. In this case the concept of impermeable surface cover should be considered out of date for municipal solid waste landfill.

\section{REFERENCES}

[1] Adani F, Tambone F., Genevini P. L., Calcaterra E.. Stabilization of Municipal Solid Waste Fractions: a laboratory approach .Technology \& Enviroment, UTA, International Edition, 1998.

[2] Blakey N.C., Bradshaw K., Reynolds P., Knox K. (1997). Bio-reactor landfill-A field trial of accelerated waste stabilisation. Proceedings Sardinia 97. Sixth International Landfill Symposium. CISA, Cagliari, vol.I, 375-386

[3] Brune M., Ramke H.G., Collins H.J., Hanert H.H. (1993) Incrustation processes in drainage systems of sanitary landfills. Proceedings Sardinia 91. Third International Landfill Symposium. CISA, Cagliari, vol.II, 999-1035.

[4] Cossu R., Raga R., Rossetti D., Experimental reduction of landfill emissions based on different concepts. The PAF model. Proceedings Sardinia 2001. Eight International Waste Management and Landfill Symposium. CISA, Cagliari, vol. I, 219-230.

[5] Farquhar G.J. (1989) Overview of landfill liners using natural material. Proceedings Sardinia 89. Second International Landfill Symposium. CISA, Cagliari, paper IX

[6] Hanashima M. (1999). Pollution control and stabilization process by semiaerobic landfill type: the Fukuoka method. Proceedings Sardinia 99. Seventh International 
KALMAR ECO-TECH'03

Bioremediation and Leachate Treatment

KALMAR, SWEDEN, November 25-27, 2003

Waste Management and Landfill Symposium. CISA, Cagliari, vol.I, 313-325

[7] Higuchi S., Hanashima M. (1999) Wash-out solid waste landfill system. Proceedings Sardinia 99, Seventh International Waste Management and Landfill Symposium, eds. T.H. Christensen, R. Cossu, R. Stegmann, CISA Publisher,Italy, vol. I, 337-344

[8] Hudgins M., S. Harper (1999).Operational Characteristics of two aerobic landfill systems. Proceedings Sardinia 99. Seventh International Waste Management and Landfill Symposium. CISA, Cagliari, vol.I, 327-333

[9] Karnik M., Parry C. (1997). Cost implication of operating landfills as flushing bioreactors. Proceedings Sardinia 97. Sixth International Landfill Symposium. CISA, Cagliari, vol.I, 419-426

[10] Kruempelbeck I.\& Ehrig H.-J (1999). Long term behaviour of municipal solid waste landfills in Germany. Proceedings Sardinia 99, Seventh International Waste Management and Landfill Symposium, eds. T.H. Christensen, R. Cossu, R. Stegmann, CISA Publisher,Italy, vol. I, 27-36

[1 1] Leikam K., Stegmann R. (1997). Mechanical biological pretreatment of residual municipal solid waste and the landfill behaviour of pretreated waste. Proceedings Sardinia 97. Sixth International Landfill Symposium. CISA, Cagliari, vol.I, 463-474

[12] Matsufuji Y., Tachifuji A., Hanashima M. Improvement technology for sanitary landfills by semiaerobic landfill concept. Proceedings APLAS 2000 Landfill Symposium. Fukuoka, Japan, 163-169

[13] Matsufuji Y., Sakai M., Tsuji K., Saito H. Safety closure and reuse of completed landfill sites by using the recirculatory semi aerobic landfill system. Proceedings Sardinia 2001. Eight International Waste Management and Landfill Symposium. CISA, Cagliari, vol. IV, 541-550.

[14] Matsuto T., Tanaka N., Koyama K. (1991). Stabilization mechanism of leachate from semi-aerobic sanitary landfills of organic-rich waste. Proceedings Sardinia 91. Third International Landfill Symposium. CISA, Cagliari, vol.I, 876-888

[15] Novella P.H., Ekama G.A., Blight G.E. (1997). Effects of liquid replacement strategies on waste stabilisation at pilot scale. Proceedings Sardinia 97. Sixth International Landfill Symposium. CISA, Cagliari, vol.I, 387-396

[16] Purcell B.E., Sollars C.J., Butler A.P. (1997). Enhanced moisture movement in simulated landfill environments. Proceedings Sardinia 97. Sixth International Landfill Symposium. CISA, Cagliari, vol.I, 409-418

[17] Robinson H. (1998). Alternatives to mechanical-biological pre-treatment. Proceedings International Seminar: Present and future of MSW landfilling. Edizioni 
Eurowaste, Padova.

[18] Rollin A.L., Mlynarek J., Lafleur J., Zanescu A. (1991) The investigation of a seven year old HDPE geomembrane used in a landfill. Proceedings Sardinia 91. Third International Landfill Symposium. CISA, Cagliari, vol.II, 667-677

[19] Scheelhaase T., Bidlingmaier W. (1997) Effects of mechanical biological pretreatment of residual waste and landfilling. Proceedings Sardinia 97. Sixth International Landfill Symposium. CISA, Cagliari, vol.I, 475-484

[20] Steagmann R., Heyer K.-U., Landfill concept for mechanical-biologically treated residual waste. Proceedings Sardinia 2001. Eight International Waste Management and Landfill Symposium.C ISA, Cagliari, vol. I, 219-230. 381-388

[21] Walker A.N., Beaven R.P., Powrie W. (1997). Overcoming problems in the development of a high rate flushing bioreactor landfill. Proceedings Sardinia 97. Sixth International Landfill Symposium. CISA, Cagliari, vol.I, 397-408

[22] Wingfield-Hayes C., Fleming G., Gronow J. (1997). Field trials of waste manipulation tecniques: the Mid Auchencarroch experimental landfill. Proceedings Sardinia 97. Sixth International Landfill Symposium. CISA, Cagliari, vol.I, 311-322. 